\title{
Summarizing Two Expository Discourses of Compare-Contrast and Cause-Effect in Second, Fourth and Sixth Graders
}

\author{
Bo Rim Kim ${ }^{a}$, Hyojin Yoon ${ }^{\mathrm{b}}$ \\ ${ }^{a}$ Chamsarang Clinic of the Mental Health Department, Gwangju, Korea \\ ${ }^{b}$ Department of Speech-Language Pathology, Chosun University, Gwangju, Korea
}

Correspondence: Hyojin Yoon, $\mathrm{PhD}$

Department of Speech-Language Pathology,

Chosun University, 309 Pilmun-daero, Dong-gu,

Gwangju 61452, Korea

Tel: $+82-62-230-7462$

Fax: +82-62-230-6271

E-mail: hjyoon0714@gmail.com

Received: October 22, 2018

Revised: November 16, 2018

Accepted: November 16, 2018

This paper is based on the master's thesis of the first author.

\begin{abstract}
Objectives: The purpose of the study is to examine the ability of expository summarization for second, fourth and sixth graders. Specifically, this study focused on macrostructure and microstructure in two expository discourse types (i.e., compare-contrast and cause-effect structure). Methods: A total of 45 students from three grade groups participated. All participants had no problems in intelligence, language, and reading. After participants read two expository discourses, they were asked to fill in the graphic organizers, and to summarize the texts verbally using graphic organizers. Analyses of oral summaries included overall organization, with coherence as macrostructure and language markers as microstructure. In order to examine differences between the three grade groups in each expository discourse, a one-way ANOVA was used. Results: There were significant differences between groups on summarizing two expository discourses, showing that organization, coherence, and language markers significantly increased as students got older. In particular, all three groups were different with each other in regards to coherence. Conclusion: The results showed that as students got older, their summarizing skills developed. That is, students have the ability to be aware of text structure, integrate the incoming information with one's background knowledge, identify main ideas and supporting ideas, and produce sophisticated vocabularies and complex syntactic structures. Summarizing expository discourse would be one effective way to evaluate and intervene with school-aged children because it provides knowledge of macrostructure and microstructure in expository discourses.
\end{abstract}

Keywords: School-aged children, Expository discourse, Summarizing, Organization, Coherence, Vocabulary, Syntactic complexity
학년이 올라갈수록 교과과정에서 제시된 이야기담화나 설명/설 득 담화가 증가하게 되고, 학생들도 점차 이러한 담화를 이해하고 표현하는 능력이 발달하게 된다(Kamhi \& Catts, 2012).

설명담화는 일반적으로 새로운 정보나 개념 등을 전하는 담화 유형으로 정보나 사건 등을 정확하고 객관적으로 전달해야 한다. 대화나 이야기와 같은 담화 유형과 비교하여 문어(literate language) 특성이 강하고 형식성이 높은 담화 유형이다(Lee \& Jung, 2013). 이 러한 설명담화의 특성은 글에 포함된 어휘와 구문에서도 나타나는 데 이야기담화보다 설명담화에서 저빈도 어휘의 사용이나 복잡한
구문의 사용이 빈번하다(Lee \& Lee, 2014; Scott \& Stokes, 1995). 이 야기담화가 시간순서나 주인공에 초점을 두어 나열된다면 설명담 화는 전하고자 하는 내용의 목적에 따라 여러 구조로 조직화될 수 있다(Kieras \& Polson, 1985). 설명담화는 특성과 조직에 따라 수집 (collection), 비교/대조(compare-contrast), 원인/결과(cause-effect), 문제/해결(problem-solution) 등의 구조로 나눌 수 있으며(Meyer \& Freedle, 1984), 초등 교과과정에는 이 4가지 구조의 설명담화가 모두 빈번하게 포함되어 있다. 초등 2 학년 교과과정에서 비교적 단 순한 구조를 가진 수집 구조가 제시되기 시작하며 3학년부터는 원 
인/결과와 비교/대조 구조가 나타난다. 4 학년부터는 문제/해결 구 조를 배우기 시작하여 6학년에는 설명담화의 전반적인 구조가 모 두 나타나게 된다(Ju, 2016).

설명담화를 이해하고 표현하는 과정은 복잡하고 높은 수준의 인지처리과정을 거쳐야 한다(Lundine et al., 2018; Westby, Culatta, Lawrence, \& Hall-Kenyon, 2010). 설명담화를 적절하게 이해하기 위해서는 제시된 글의 내용과 자신이 가지고 있는 배경지식(background knowledge)을 통합해야 하고, 이해 모니터링(comprehension monitoring)을 통해 자신의 이해정도를 점검할 수 있어야 한 다. 그리고 글에 명시되지 않은 정보는 추론을 통하여 글의 전반적 인 내용에 대한 표상을 구축해야 한다. 설명담화를 이해하는 과정 은 이렇게 다양한 상위인지전략이 요구되는 과정이라고 할 수 있 다. 그 뿐만 아니라 설명담화 구조에 대한 인식 능력(awareness of text structure)도 설명담화의 이해와 표현에 중요한 영향을 미치게 된다(Ray \& Meyer, 2011). 설명담화 구조에 대한 인식이란 설명담 화가 어떻게 논리적으로 조직되었는지를 아는 것이다(Meyer \& Rice, 1982). 예를 들면 비교/대조의 설명담화 구조는 둘 이상의 사 물이나, 사건, 개념 등에 대해 비슷한 점과 차별점을 구별할 수 있어 야 하며, 원인/결과의 설명담화 구조는 선행하는 사건에 원인을 기 술한 후, 결과에 해당하는 내용을 기술하는 구조임을 아는 것이다. 즉, 각 구조에 대한 인식 능력이 있다면 어떤 설명담화를 접하더라 도 이를 토대로 내용을 적절하게 이해할 수 있고, 표현을 할 때도 내 용을 명확하게 조직화할 수 있는 것이다(Kintsch, 2004).

지금까지의 학령기 설명담화에 대한 선행연구들은 설명담화의 산출에서 나타난 어휘와 구문 등의 미시구조(microstructure)적인 측면에 초점을 두었다(Ahn \& Kim, 2010; Lee \& Jung, 2013; Lee \& Lee, 2014; Nippold, Hesketh, Duthie, \& Mansfield, 2005). 미시구 조는 개별 문장에 대한 것으로, 연구자들은 미시구조 분석에서 각 문장의 어휘나 구문에 초점을 둔 분석을 하였다. 어휘는 주로 총 낱 말수와 서로 다른 낱말수로, 구문복잡성은 T-unit당 낱말수와 Tunit당 어절수, 절밀도 등으로 살펴보았다. 설명담화 쓰기를 통해 어휘와 구문복잡성을 살펴본 Ahn과 $\operatorname{Kim}$ (2010)의 연구에 따르면 총 낱말수와 서로 다른 낱말수 모두 학년이 올라갈수록 다양하고 풍부한 어휘로 표현할 수 있을 뿐 아니라 구문적으로도 복잡해지 는 것으로 나타났다. 일부 연구는 설명담화의 구조에 따른 미시구 조적 차이를 분석하기도 하였다. Lee와 Lee (2014)는 설명담화 구조 에 따라 서로 다른 낱말수와 C-unit당 평균낱말길이에 차이가 있 는지를 살펴보았다. 연구 결과 수집구조가 문제/해결 구조보다 서 로 다른 낱말수, 총 C-unit 수, 그리고 C-unit당 평균낱말길이 모두 에서 유의하게 긴 것으로 나타나 설명담화의 구조에 따른 차이가
있다는 것을 보고하였다.

설명담화의 개별적 문장의 특성에 초점을 둔 연구들도 중요하지 만 설명담화의 전반적인 내용에 대한 거시구조(macrostructure)적 인 측면을 살펴보는 것도 필요하다. 거시구조는 각 문장과 문단들 이 얼마나 통일성을 가지고 긴밀하게 연결되어 있는지에 대한 것이 다(Brown \& Day, 1983). 복잡한 언어구조로 구성된 설명담화는 글 의 거시구조인 응집성과 결속성, 의미성이 담보되어야 한다 $(\mathrm{Ow}-$ ens, 2012). 학령기 아동의 설명담화 산출에서 나타난 거시구조의 특성은 설명담화 구조에 대한 인식으로 조직성을 살펴보거나(Englert \& Hiebert, 1984; Meyer \& Freedle, 1984; Ray \& Meyer, 2011; Wyile \& McGuinness, 2004), 중심문장과 중심문장을 뒷받침하는 내용들의 긴밀성 분석을 통한 응집성 등으로 살펴보았다(Westby \& Clauser, 2005). 학년 간 설명담화 구조 인식에 대한 발달을 살펴 본 Englert와 Hiebert (1984), Ray와 Meyer (2011)에서는 학년이 올 라갈수록 설명담화 구조에 대한 인식 능력이 명확해지고, 구조의 흐름을 방해하는 문장을 제외할 수 있는 능력이 증진된다고 보고 하였다. 특히, 9 학년까지 살펴본 Ray와 Meyer (2011)의 연구에서는 학년이 올라갈수록 구조에 대한 인식이 명확해져 설명담화를 잘 조직하여 산출하거나 이해할 수 있으나 학년이 올라갈수록 증가의 폭이작아진다고 하였다.

설명담화의 산출 특성에 대한 연구는 다양한 방법으로 실시되었 다. 그중 요약하기는 조직성이나 응집성과 같은 거시구조뿐 아니라 어휘나 구문복잡성과 같은 미시구조도 함께 살펴볼 수 있다(Marzano, Pickering, \& Pollock, 2001; Sudweeks, Glissmeyer, Morrison, Wilcox, \& Tanner, 2003). 요약하기는 다시 말하기(retelling) 이상 의 능력을 필요로 한다. 다시 말하기 과제는 들은 내용의 구조를 단 기기억과 장기기억 속에 가능한 잘 저장했다가 인출하는 것이라면 (Lundine et al., 2018), 요약하기는 텍스트에 대한 표상을 구축해야 하는 좀 더 높은 수준의 인지처리과정을 거쳐야 한다(Westby et al., 2010). 즉, 요약할 때에는 글의 정보를 분석하고, 중요한 것과 중요하 지 않은 것을 구별할 수 있어야 하며, 많은 정보를 짧지만 응집력 있 는 문장으로 바꾸는 기술이 필요하다. 또한 중심문장을 확인하고, 문장 간 긴밀성을 높이기 위해 어휘, 연결어미나 접속사와 같은 결 속표지를 적절하게 사용할 수 있어야 한다(Graesser \& Li, 2013). 특 히, 정보전달을 목적으로 하는 설명담화에서는 이러한 결속표지를 적절하게 사용하여 글의 구조가잘 드러나도록 표현해야한다(Yoon, 2008). 마지막으로 설명담화를 요약하는 능력은 구조에 대한 인식 능력이 수반이 되어야 내용의 흐름을 논리적으로 구성할 수 있다. 이러한 과정을 통해 산출된 설명담화의 요약하기는 설명담화를 적 절하게 산출할 수 있는지를 살펴보는 데 유용한 방법이다. 도식은 
설명담화의 중재에서 빈번하게 사용되지만(National Reading Panel, 2000) 평가에서도 중요한 척도가 될 수 있다(Westby et al., 2010).

요약하기 능력은 초등학교 저학년 시기부터 미약하지만 발달하 기 시작하여 성인이 될 때까지 지속적으로 발달한다(Kintsch, 1990). 우리나라의 초등교과과정에서도 저학년부터 설명담화 요약하기 활동을 통해 설명담화를 교육하고 있고, 교육활동 내에서도 중심 내용과 세부내용 확인하기, 중심단어 찾기 등이 포함되어 있다(Jung, 2011).

하지만 교과과정에서 빈번하게 노출됨에도 불구하고 설명담화 요약하기 능력이 어떻게 발달하는지에 대한 연구는 제한적이다. 특 히, 대부분의 연구가 미시구조를 살펴보는 데 초점을 두고 있어 거 시구조 특성을 살펴보는 연구가 필요한 시점이다. 따라서 본 연구 는 초등학교 2, 4, 6학년 아동을 대상으로 하여 설명담화를 글로 제 시한 후 구어로 요약하도록 하고, 이를 통해 거시구조와 미시구조 의 특성을 살펴보고자 한다. 초등 저학년부터 교과서에서 빈번하 게 제시되는 비교/대조 구조와 원인/결과의 두 설명담화 구조에 중 심으로 살펴보고자 한다. 본 연구에서는 설명담화 유형 각각에 나 타난 요약하기 특성에 초점을 두었는데, 이는 두 설명담화 주제의 친숙성이 다르고, 이러한 친숙성의 정도가 요약하기에 영향을 미 칠 수 있기 때문에 유형 간의 비교는 다루지 않았다. 요약하기의 거 시구조는 조직성과 응집성으로, 미시구조는 어휘와 구문복잡성으 로 살펴보았다.

\section{연구방법}

\section{연구대상}

본 연구의 대상은 광주.전라지역의 초등학교 $2,4,6$ 학년 각 15 명, 총 45 명으로 언어, 읽기, 인지 발달에 어려움이 없는 아동이다. 연구 대상 선정기준은 다음과 같다. 첫째, 한국어 비언어지능검사-II (Korean version of Comprehensive Test of Nonverbal Intelligence second edition; Park, 2014)를 실시했을 때, 매뉴얼의 지능분류에 따라 평균 이상인 80점 이상인 아동을 선정하였다. 둘째, 수용-표 현어휘력검사(Receptive \& Expressive Vocabulary Test, REVT; Kim, Hong, Kim, Jang, \& Lee, 2009) 결과, -1 표준편차 이상인 아 동을 선정하였다. REVT 지침서에 따르면 - 1 표준편차 이상을 정상 발달 내에 있는 것으로 보았기 때문에 -1 표준편차 이상으로 선정 하게 되었다. 셋째, 한국어읽기검사(Korean Language-based Reading Assessment, KOLRA; Pae, Kim, Yoon, \& Jang, 2015) 중 읽기유창 성검사에서 아동의 생활연령에 비교했을 때 표준점수 90 점 이상인 아동을 선정하였다. 본 연구는 대상자가 직접 글을 읽고 요약하는
Table 1. Participants' characteristics $(N=45)$

\begin{tabular}{lrcc}
\hline & $\begin{array}{c}\text { 2nd grade } \\
(\mathrm{N}=15)\end{array}$ & $\begin{array}{c}\text { 4th grade } \\
(\mathrm{N}=15)\end{array}$ & $\begin{array}{c}\text { 6th grade } \\
(\mathrm{N}=15)\end{array}$ \\
\hline Age $(\mathrm{mo})$ & $95 \pm 2.10$ & $120 \pm 3.08$ & $145 \pm 4.25$ \\
K-CTONI-2 (score) & $104.3 \pm 10.3$ & $107.33 \pm 7.17$ & $107.66 \pm 10.54$ \\
REVT $^{\mathrm{b}}$ & & & \\
$\quad$ Receptive vocabulary (raw score) & $91.80(4.88)$ & $113.06(5.21)$ & $132.93(6.05)$ \\
$\quad$ Expressive vocabulary (raw score) & $91.46(5.35)$ & $110.06(3.87)$ & $135.20(6.10)$ \\
KOLRA reading fluency (score) & $105.93 \pm 4.71$ & $105.66 \pm 3.57$ & $105.33 \pm 3.90$ \\
\hline
\end{tabular}

Values are presented as mean $\pm \mathrm{SD}$.

CTONI-2 = Korean Comprehensive Test of Nonverbal Intelligence-2 (Park, 2014); REVT = Receptive and Expressive Vocabulary Test (Kim, Hong, Kim, Jang, \& Lee, 2009); KOLRA=Korean Language-Based Reading Assessment (Pae, Kim, Yoon, \& Jang, 2015).

과제로, 읽기에 어려움이 없는 학생들을 대상으로 하였다. 읽기부 진에 대한 저성취 모델에 근거하여 표준점수 90 점 이상으로 선정하 게 되었다. 넷째, 모든 아동은 부모나 교사에 의해 감각, 인지, 신경 학적 문제가 없다고 보고된 아동으로 특수교육대상자로 선정되지 않은 아동이다. 각 집단에 선정된 2, 4, 6학년의 연령, K-CTONI-2, REVT, KOLRA 읽기유창성검사의 평균(표준편차)은 Table 1 과 같다.

\section{검사도구}

본 연구에서는 초등 $2,4,6$ 학년의 설명담화 구조에 따른 요약하 기 발달을 보기 위해 글 수준을 중간 학년(초등 4 학년)에 맞추어 제 작하였다. 설명담화는 초등학교 저학년부터 빈번하게 제시되는 비 교/대조와 원인/결과의 두 설명담화 구조를 선택하였다.

비교/대조의 설명담화 주제는 '호랑이와 토끼'이며, 원인/결과 설 명담화 주제는 '우리나라도 지진의 안전지대가 아니다'이다. '호랑 이와 토끼'는 한국어 해독해 3권(Jung, Jin, Gwak, Kim, \& Pae, 2017) 워크북을 참고하여 제작하였으며, 원인/결과 설명담화의 주제인 '지진'은 3-5학년 교과서를 참고하여 연구자가 직접 제작하였다. 두 설명담화 모두 ‘초등 교과 어휘 자료집’을 참고하여 글의 $90 \%$ 이상 이 3-5학년 교과서에서 출현하는 어휘들로 구성될 수 있도록 하였 으며, Nippold (2007)에서 제시한 설명담화에 자주 제시되는 결속 표지들을 사용하여 설명담화의 글을 제작하였다.

두 설명담화는 어휘의 난이도와 구문의 길이가 비슷하도록 구성 하였다. 비교/대조의 설명담화는 28 문장의 글로 구성되어 있으며, 34 개의 T-unit으로 구성하였다. 글 안에 복문은 16 문장이며, 종속 절 13 개가 포함되었다. 원인/결과 구조의 설명담화는 25 문장으로 구성하였고, 31 개의 T-unit이 있다. 복문은 14 개이며, 13 개의 종속 절을 포함하고 있다.

글을 읽은 후 구어로 요약하기 전에 대상자에게 먼저 도식을 채 
우도록 요구하였고, 이때 제시하는 도식은 Westby 등(2010)의 연구 에 제시된 도식을 참고로 하여 제작하였다.

설명담화의 주제, 어휘와 형태구문, 도식과 채점이 적절한지에 대 한 내용 타당도는 국어국문학 박사학위 소지자 1 인, 10 년 이상의 경 력을 가진 초등학교 일반교사 2 인, 언어병리학 교수 1 인과 언어재활 사 경력 8년 이상이며 언어병리학 박사학위 소지자 2인에게 의뢰하 였다. 내용타당도 지수는 Likert 5점 척도로 실시하였으며, 평균 내 용타당도를 산출한 결과, 비교/대조 설명담화의 경우 평균 4.2점이 었으며, 원인/결과 설명담화의 경우 평균 4.1점이었다.

\section{연구절차}

검사는 아동이 다니는 초등학교 혹은 집 등 조용한 공간에서 진 행하였다. 검사자와 아동이 일대일로 하여 검사를 실시하였으며, 아동당 약 1 시간 정도의 시간이 소요되었다.

연구자는 본 연구과제를 실시하기 전에 연습과제를 통해 과제에 대한 이해도를 도왔다. 연습과제는 본 연구과제에서 사용되는 동일 한 설명담화 구조인 비교/대조와 원인/결과 구조이다. 연습 과제에 사용된 글도 제작하였으며, 글 제목은 '자전거와 오토바이', '눈이 나빠지는 원인'으로 본 연구 과제에 영향을 주지 않는 주제로 선택 하였다. 연습 문항은 약 15 문장으로 구성되어 있으며, 본 연구과제 보다 어휘와 구문의 난이도를 쉽게 제작하였다. 연구자는 연습 과 제에 대한 설명담화 글과 도식자료를 보여주면서 "선생님이 이제부 터 이야기를 2 개 보여줄 거예요. $\bigcirc \bigcirc$ 이가 읽고 나서 옆에 있는 도 식의 네모를 채우는 거예요. 그 다음에 도식만 보고 선생님에게 하 나의 이야기로 말해주세요.”라고 설명한다. 연습과제에서 아동이 자발적으로 도식을 채우는 것이 어렵다면 연구자가 다시 한 번 과 제에 대해 설명하면서 도식 채우는 것을 도와주었다. 연습과제를 실시한 후 본 연구과제를 실시하였으며, 아동에게 "이제는 $\bigcirc \bigcirc$ 이 스스로 도식을 채우고 이야기할 거예요. $\bigcirc \bigcirc$ 이가 읽고 나서 옆에 있는 도식의 네모를 채우는 거예요. 그 다음에 도식만 보고 아까처 럼 하나의 이야기로 말해주세요”라고 설명하였다.

\section{자료분석}

요약하기의 채점은 Westby 등(2010)이 제시한 설명담화 요약하 기 채점 기준을 참고하여 수정 후 사용하였다. Westby 등(2010)은 거시구조 측면에서 도식 사용하여 요약하기, 설명담화 구조 인식하 기, 중심문장, 문장 간 긴밀성, 결속표지, 문장구조의 6가지 지표로 채점하였다. 본 연구에서는 Westby 등(2010)이 사용한 6가지 지표 를 조직성, 응집성 두 가지 측면으로 나누고, 도식 채우기 채점 기준 을 추가하고, 결속표지에 대한 기준을 우리말에 맞게 수정하여 총
6가지 지표로 거시구조를 채점하였다. 도식 채우기가 포함된 이유 는 요약할 때 글을 읽고 필요한 문장과 불필요한 문장을 구별하여 도식에 적절한 내용을 채울 수 있어야 하고, 도식 채우기가 어렵다 면 도식을 사용하여 요약하는 것이 어렵기 때문이다. 그래서 거시 구조의 측면에 '도식 채우기' 채점 기준을 추가하였다. 미시구조 측 면은 서로 다른 낱말수(number of different words, NDW), C-unit 당 평균낱말길이(mean length of C-unit word, MLC_w)와 C-unit 당 평균종속절수(mean number of clauses in a C-unit, $\mathrm{MNC}$ )를 분석하여 객관적 수치를 제공하였다.

우선 조직성은 '도식 채우기, 도식 사용하여 요약하기, 설명담화 구조 인식 하기'의 3 가지 지표를 측정하였으며, 도식을 자발적으로 채우고, 도식을 이용하여 스스로 글을 조직화하고, 글의 구조를 인 식하여 결과적으로 구조가 명확하게 드러날 수 있도록 요약하는지 를 평가하였다. 둘째, 응집성은 '중심 문장, 문장 간의 긴밀성, 결속 표지'의 3 가지 지표로 채점하였으며, 글 내용을 포괄할 수 있는 중 심 문장이 있는지, 문장과 문단 간 얼마나 긴밀하게 연결하는지, 그 리고 이때 결속표지를 적절하게 사용하였는지를 평가하였다. 마지 막으로 미시 구조 측면인 언어적 표지는 전체 요약하기 발화에 나 타난 NDW와 MLC-w, MNC로 측정하였으며, MLC-w는 총 낱말 의 수를 총 C-unit의 수로 나누어 구한다. MNC는 아동의 구문복 잡성을 평가하는 지표로서 C-unit당 주절과 종속절을 포함하는 절의 수를 산출한다. 계산 방법은 주절과 종속절을 더한 후, 총 Cunit으로 나누어 구하며, 종속절의 기준은 Kwon과 Pae (2006)를 따랐다.

채점은 조직성에 포함된 ‘도식 채우기’만 아동이 작성한 도식으 로 채점하였으며, 나머지 요소는 아동이 구어로 산출한 요약하기 발화에 대해 채점하였다. 조직성, 응집성에 해당하는 지표는 모두 3 점 척도 $(0=$ 전혀 그렇지 않다, $1=$ 약간 적절하다, $2=$ 적절하다 $)$ 로 채점하여 조직성과 응집성 총 점수는 각각 6 점(3가지 지표 $\times 2$ 점) 이다. 세부적인 채점기준은 Appendix 1에 제시하였다. 언어적 표지 에 해당하는 점수는 NDW, MLC-w, MNC를 계산하였다.

채점에 대한 신뢰도 검증을 위하여 제 1 평가자는 본 연구의 연구 자이며, 언어병리학 석사과정 1 인이 제 2 평가자로서 검사자 간 신뢰 도를 산출하였다. 제 2 평가자는 채점하기 전에 거시구조에 해당하 는 채점 기준과 미시구조를 분석하기 위한 낱말, C-unit, 종속절의 분석기준을 숙지하도록 하였다. 전체 수집된 자료의 $20 \%$ 를 임의로 선정하여 채점한 후 $94.4 \%$ 의 일치도가 나왔고, 일치되지 않는 부분 은 두 평가자가 논의를 통해 최종적으로 검사자 간 채점 신뢰도는 $100 \%$ 로 나타났다. 


\section{자료의 통계처리}

통계분석은 SPSS for Windows 21.0을 사용하였다. 설명담화 구 조별로 각 학년 간에 요약하기의 조직성, 응집성, 언어적 표지 요소 에 유의한 차이가 있는지를 살펴보기 위해 일원분산분석(one-way ANOVA)을 실시하였으며, 어느 집단 간에 유의한 차이가 있는지 를 알아보기 위해 Tukey 사후검정을 실시하였다.

\section{연구결과}

설명담화 구조에 따라 각 학년 집단 내에서 요약하기 능력에 차 이가 있는지를 살펴보았다. 비교/대조 $(F=74.916, p<.001)$ 와 원인/ 결과 $(F=60.181, p<.001)$ 설명담화 구조 모두에서 요약하기 능력 은 학년에 따라 차이가 있는 것으로 나타났으며, 모두 학년 간에 유 의한 차이가 있는 것으로 나타났다. 설명담화의 요약하기 점수는 조직성, 응집성, 언어적 표지로 나누어 살펴보았고, 다음에 각 설명 담화별로 제시하였다.

\section{집단에 따른 설명담화 요약하기 조직성 점수 비교}

$2,4,6$ 학년 아동의 요약하기 조직성 점수를 분석하여 기술통계 를 실시한 결과, 두 설명담화 모두에서 학년이 올라감에 따라 총 점 수 및 도식 채우기, 도식 사용하여 요약하기, 설명담화 구조 인식하 기의 평균 점수가 증가하였다.

비교/대조와 원인/결과 설명담화에서 세 집단 간 차이가 있는지를 살펴보기 위해 일원분산분석(ANOVA)을 실시하였고, 결과는 Table 2 에 제시하였다. 비교/대조 설명담화에서는 도식 채우기 $(F=12.07$, $p<.001)$, 도식 사용하여 요약하기 $(F=55.74, p<.001)$, 설명담화 구조 인식하기 $(F=19.41, p<.001)$, 조직성 총 점수 $(F=39.02, p<.001)$ 모두

Table 2. Scores of organization in three groups

\begin{tabular}{lcccc}
\hline & 2nd grade & 4th grade & 6th grade & $F$ \\
\hline Compare-contrast & & & & \\
$\quad$ Filling a graphic organizer & $.66 \pm .61$ & $1.20 \pm .56$ & $1.66 \pm .48$ & $12.07^{* * *}$ \\
Summarizing a graphic organizer & $.86 \pm .35$ & $1.80 \pm .41$ & $2.0 \pm .0$ & $55.74^{* * *}$ \\
Text structure & $.66 \pm .48$ & $1.46 \pm .51$ & $1.73 \pm .45$ & $19.41^{* * *}$ \\
Total scores & $2.20 \pm 1.01$ & $4.46 \pm 1.24$ & $5.40 \pm .73$ & $39.02^{* * *}$ \\
Cause-effect & & & & \\
Filling a graphic organizer & $.46 \pm .63$ & $1.00 \pm .75$ & $1.80 \pm .41$ & $17.58^{* * *}$ \\
Summarizing a graphic organizer & $.86 \pm .35$ & $1.46 \pm .51$ & $1.93 \pm .25$ & $28.14^{* * *}$ \\
Text structure & $.53 \pm .51$ & $1.26 \pm .59$ & $2.00 \pm .0$ & $39.09^{* * *}$ \\
Total scores & $1.86 \pm 1.12$ & $3.73 \pm 1.43$ & $5.73 \pm .45$ & $47.49^{* * *}$ \\
\hline
\end{tabular}

Values are presented as mean $\pm S D$.

${ }^{* * *} p<.001$.
집단 간 유의한차이를 보였다(Table 2). Tukey 사후검정을 통해 어느 집단 간에 차이가 있는지를 살펴본 결과 도식 채우기, 도식 사용하여 요약하기, 설명담화 구조 인식하기와 조직성 총 점수 모두 2학년과 4 학년 간, 2 학년과 6 학년 간에서 유의한차이가 나타났다.

원인/결과 설명담화에서도 도식 채우기 $(F=17.58, p<.001)$, 도식 사용하여 요약하기 $(F=28.14, p<.001)$, 설명담화 구조 $(F=39.09$, $p<.001)$, 조직성 총 점수 $(F=47.49, p<.001)$ 모두에서 집단 간 유의 한 차이가 있는 것으로 나타났다. Tukey 사후검정을 실시한 결과, 도식 채우기는 2학년과 6학년 간, 4 학년과 6학년 간 유의한 차이를 보였으며, 도식 사용하여 요약하기, 설명담화 구조 인식하기, 조직 성 총 점수는 2 학년과 4 학년 간, 2 학년과 6 학년 간, 4 학년과 6 학년 간에서 유의한 차이를 보였다.

\section{집단에 따른 설명담화 요약하기 응집성 점수 비교}

요약하기 응집성 점수를 분석한 결과 비교/대조와 원인/결과 설 명담화 구조 모두 학년이 올라감에 따라 총 점수 및 중심 문장, 문 장 간의 긴밀성, 결속표지의 평균 점수가 증가하였다.

각 학년 집단별로 통계적으로 유의한 차이를 보이는지 알아보기 위하여 일원분산분석(ANOVA)을 실시한 결과, 비교/대조 설명담 화에서는 중심문장 $(F=25.98, p<.001)$, 문장 간 긴밀성 $(F=21.14$, $p<.001)$, 결속표지 $(F=18.37, p<.001)$, 응집성 총 점수 $(F=55.48$, $p<.001)$ 모두 집단 간 유의한 차이를 보였다. Tukey 사후검정을 실 시한 결과 중심문장, 문장 간의 긴밀성, 결속표지, 응집성 총 점수 모두 2학년과 4학년 간, 2 학년과 6 학년 간, 4 학년과 6 학년 간에서 유의한 차이를 보였다.

원인/결과 설명담화에서도 중심문장 $(F=27.11, p<.001)$, 문장 간 의 긴밀성 $(F=26.19, p<.001)$, 결속표지 $(F=23.02, p<.001)$, 응집성

Table 3. Scores of coherence in three groups

\begin{tabular}{lcccc}
\hline & 2nd grade & 4th grade & 6th grade & $F$ \\
\hline Compare-contrast & & & & \\
Main sentence & $.13 \pm .35$ & $.80 \pm .41$ & $1.40 \pm .63$ & $25.98^{* * *}$ \\
Coherence between sentences & $1.00 \pm .0$ & $1.4 \pm .63$ & $1.93 \pm .25$ & $21.14^{* * *}$ \\
Coherence marker & $.33 \pm .48$ & $1.06 \pm .7$ & $1.60 \pm .52$ & $18.37^{* * *}$ \\
$\quad$ Total score & $1.46 \pm .63$ & $3.4 \pm 1.18$ & $4.93 \pm .79$ & $55.48^{* * *}$ \\
Cause-effect & & & & \\
Main sentence & $.13 \pm .35$ & $.66 \pm .48$ & $1.33 \pm .48$ & $27.11^{* * *}$ \\
Coherence between sentences & $.66 \pm .48$ & $1.13 \pm .51$ & $1.86 \pm .35$ & $26.19^{* * *}$ \\
Coherence marker & $.53 \pm .51$ & $1.26 \pm .59$ & $1.80 \pm .41$ & $23.02^{* * *}$ \\
Total score & $1.33 \pm .97$ & $3.33 \pm 1.29$ & $4.86 \pm 1.12$ & $36.35^{* * *}$ \\
\hline
\end{tabular}

Values are presented as mean $\pm S D$.

${ }^{* * *} p<.001$. 
Table 4. Scores of linguistic markers in three groups

\begin{tabular}{lcccc}
\hline & 2nd grade & 4th grade & 6th grade & $F$ \\
\hline Compare-contrast & & & & \\
NDW & $35.6 \pm 10.11$ & $80.33 \pm 34.82$ & $92.66 \pm 30.74$ & $17.95^{* * *}$ \\
MLC-w & $6.99 \pm 1.98$ & $10.2 \pm 3.09$ & $12.23 \pm 2.98$ & $14.06^{* * *}$ \\
MNC & $1.06 \pm .12$ & $1.18 \pm .16$ & $1.21 \pm .14$ & $4.29^{*}$ \\
Cause-effect & & & & \\
NDW & $75.93 \pm 28.25$ & $101.73 \pm 21.93$ & $124.66 \pm 34.61$ & $10.80^{* * *}$ \\
MLC-w & $7.65 \pm 2.39$ & $9.2 \pm 1.72$ & $14.03 \pm 5.95$ & $11.3^{* * *}$ \\
MNC & $1.28 \pm .12$ & $1.44 \pm .16$ & $1.58 \pm .36$ & $5.68^{* *}$ \\
\hline
\end{tabular}

Values are presented as mean \pm SD.

$\mathrm{NDW}=$ number of different words; $\mathrm{MLC}-\mathrm{W}=$ mean length of $\mathrm{C}$-unit word; $\mathrm{MNC}=$ mean number of clauses in a $\mathrm{C}$-unit.

${ }^{*} p<.05,{ }^{* *} p<.01,{ }^{* * *} p<.001$

총 점수 $(F=36.35, p<.001)$ 모두 집단 간 유의한 차이가 있었다. 집 단에 따른 차이가 있는지를 살펴보기 위해 Tukey 사후검정을 실시 한 결과 중심문장, 문장 간의 긴밀성, 결속표지, 응집성 총 점수는 2 학년과 4학년 간, 2 학년과 6학년 간, 4 학년과 6 학년 간에 통계적으 로 유의한 차이가 있는 것으로 나타났다(Table 3).

\section{집단에 따른 설명담화 요약하기 언어적 표지 점수 비교}

언어적 표지는 서로 다른 낱말수(NDW), C-unit당 평균낱말길 이(MLC-w)와 C-unit당 평균종속절길이(MNC)를 분석하였다. 두 설명담화구조 모두에서 학년이 올라감에 따라 NDW, MLC-w와 $\mathrm{MNC}$ 모두 증가하였다. 학년 집단별 차이에 대한 일원분산분석 (ANOVA)을 실시한 결과는 Table 4에 제시하였다.

비교/대조 담화에서는 NDW ( $F=17.95, p<.001), \mathrm{MLC}-\mathrm{w}(F=$ $14.06, p<.001), \mathrm{MNC}(F=4.297, p<.05)$ 모두 세 집단 간에 유의한 차이가 있는 것으로 나타났다. 학년 간 차이를 살펴보면 NDW, MLC-w는 2학년과 4학년 간, 2학년과 6학년 간에 유의한 차이가 있었으며, MNC는 2학년과 6학년 간에 유의한 차이를 보였다.

원인/결과에서도 학년 집단별로 모두 유의한 차이가 있는 것으로 나타났다. NDW ( $F=10.80, p<.001), \mathrm{MLC}-\mathrm{w}(F=11.302, p<.001)$, $\operatorname{MNC}(F=5.678, p<.01)$ 로 모두 집단 간 유의한 차이를 보였다. 사 후 검정 결과 $\mathrm{NDW}$ 는 2 학년과 4 학년, 2 학년과 6 학년 간 유의한 차 이를 보였으며, MLC-w는 2학년과 6학년 간, 4학년과 6학년 간 유 의한 차이를 보였다. $\mathrm{MNC}$ 는 2 학년과 6 학년 간에 유의한 차이를 보 이는 것으로 나타났다.

\section{논의 및 결론}

본 연구는 초등 $2,4,6$ 학년 일반아동들을 대상으로 비교/대조와
원인/결과의 설명담화를 읽은 후 구어로 요약하는 능력을 살펴보 고자 하였으며, 요약하기 능력은 거시구조인 조직성, 응집성, 그리 고 미시구조인 어휘와 구문으로 나누어 분석하였다.

연구 결과 학년이 올라갈수록 조직성, 응집성, 언어적 표지 모두 에서 각 학년 집단 간에 유의한 차이를 보이면서 설명담화 요약하 기 능력이 발달하는 것으로 나타났다.

우선 첫 번째로 설명담화 요약하기 능력을 조직성으로 살펴보았 으며, 조직성은 도식 채우기, 도식 사용하여 요약하기, 설명담화 구 조 인식하기, 그리고 이 세 지표의 총점수로 나누어 분석하였다. 비 교/대조 구조에서는 세 지표와 총 점수 모두에서 2학년과 4학년, 2 학년과 6 학년 간 유의하게 차이를 보이며 지속적으로 발달하는 것 으로 나타났다. 원인/결과 구조에서는 도식 채우기 점수가 2학년과 6학년 간에만 유의하게 증가하였으나, 도식 사용하여 요약하기, 설 명담화 구조 인식하기와 조직성 총 점수는 모든 학년 간에 유의한 점수의 증가가 있었다.

저학년은 자발적으로 설명담화 글을 요약하는 것이 어렵기 때문 에 도식을 활용하는 것이 필요하다는 연구에(Westby et al., 2010) 따라 본 연구에서는 도식을 제공하고, 학생들이 도식을 스스로 채 운 후 요약하여 말하도록 요구하였다. 2 학년 학생들은 불필요한 내 용과 필요한 내용을 확인한 후 도식을 채우는 데 어려움이 있어 도 식에 제시된 글의 문장 그대로를 적는 모습을 보였다. 두 설명담화 모두에서 2 학년 학생들은 도식에 필요한 내용의 약 $50 \%$ 정도만 채 우는 것으로 관찰되었다. 반면 4학년은 약 $78 \%, 6$ 학년은 $90 \%$ 이상 필요한 내용을 적절하게 도식에 채울 수 있었으며, 도식을 활용하 여 각 설명담화의 구조에 맞게 더 논리적으로 요약할 수 있었다. 이 러한 결과는 우선 읽기발달의 차이로 설명할 수 있다. 본 연구에서 는 읽은 후 구어로 산출하도록 유도하였는데 아직 유창성 단계로 완벽하게 넘어가지 않은 2학년 단계에서는 읽고 이해하여 요약하 는 데 어려움이 있었던 것으로 해석할 수 있다. 읽기발달단계에 따 르면 2학년 학생들은 일견단어를 늘리면서 유창성이 증가되는 시 기로 아직 글의 이해보다는 해독에 대부분의 인지적 자원을 사용 하는 시기이기 때문에(Chall, 1983), 읽은 내용을 충분히 이해하여 텍스트에 대한 심적 표상을 구성하는 데에는 어려움이 있었을 것 이다. 그래서 요약하려는 시도보다는 전반적인 문장을 글에 있는 그대로 다쓰면서 중요한 정보와 중요하지 않은 정보를 선택하는 데 어려움이 있었다고 볼 수 있다. 또한 2학년에서는 도식을 채울 때 쓰기 오류도 빈번하였는데 이를 구어로 산출할 때 수정하지 않고 그대로 표현하는 모습을 보였고, 이는 내용에 대한 충분한 이해가 없었기 때문에 구어에서도 오류를 산출한 것으로 해석할 수 있을 것이다. 반면 4학년과 6학년은 글을 유창하게 읽을 뿐 아니라 학습 
을 위한 읽기 단계로, 읽은 글을 이해하고, 도식에 중요한 정보만 적 절하게 스스로 채울수 있었다고 해석할수 있었다.

도식을 사용하여 요약하고, 이때 설명담화의 구조가 잘 드러나 도록 산출했는지를 살펴본 지표에서도 발달적 차이가 두드러지게 나타났다. 2 학년은 자발적으로 도식을 채웠음에도 불구하고 도식 을 사용하여 요약을 할 때 요약의 시도가 거의 없었으며, 연구자가 도식 내에 제공한 일부 어휘를 문맥에 맞지 않게 그대로 발화에 포 함하는 모습을 보이거나, 두 설명담화의 구조가 드러날 수 있도록 논리적 연결을 하는 데 어려움이 나타났다. 4 학년부터는 도식을 적 절하게 사용하여 논리적으로 요약할 수 있었으며, 설명담화의 구 조가 잘 드러날 수 있도록 요약할 수 있었다. 4학년 집단에서도 때 때로 도식에 제공된 문장을 그대로 발화에 포함하기는 하였으나 대체로 구어로 산출하면서 문맥에 맞게 적절하게 수정하려는 시도 를 보였으며, 각 설명담화의 구조가 드러나도록 산출하였다. 6학년 은 도식을 적절하게 사용하고 설명담화의 구조를 인식하여 요약할 때 중요한 내용과 중요하지 않은 내용을 선택하고, 도식에 필요한 정보만 적절하게 넣을 뿐 아니라 설명담화 구조에 대한 인식이 발 달하여 두 담화의 구조가 더 잘 드러나게 산출할 수 있다는 것을 보 여주었다.

학년이 올라갈수록 설명담화의 구조를 인식하여 적절하게 요약 할 수 있다는 본 연구의 결과는 중심 생각을 찾고 문장의 배열을 통 해 설명담화 구조에 대한 인식 능력을 살펴본 선행연구에서 연령이 증가할수록 구조에 대한 인식력이 명확해진다는 결과와 일치한다 (Englert \& Hiebert, 1984; Smith \& Hahn, 1989). 본 연구에서 2학 년 학생들은 설명담화 구조에 대한 인식이 부족한 것이 구어로 요 약할 때에도 나타났다. 설명담화 구조에 대한 인식은 각 문장 간의 논리적인 연결을 구체화하는 데 도움을 주는데(Meyer, Brandt, \& Bluth, 1980) 2학년은 설명담화 구조에 대한 인식이 부족하였고, 이 러한 인식 부족이 구어로 요약할 때에도 그대로 드러난 것으로 볼 수 있다. 예를 들면, 원인/결과 구조의 글은 지진이 일어나는 원인이 기술된 후, 그에 따른 결과 및 대비 방안에 대해 쓰여 있는데 2학년 학생들은 도식에 구조가 대략적으로 제시되어 있음에도 불구하고 구조에 대한 인식이 부족하여 대비 방안을 먼저 산출한 후 결과로 인한 피해 내용을 말하는 모습을 보였다. 원인/결과 구조에서는 4 학년도 6학년과 유의한 차이를 보였는데 이는 비교/대조 구조보다 원인/결과 구조의 인식이 더 어렵기 때문으로 볼 수 있다(Ghaith \& Harkouss, 2003). 비교/대조는 두 사물이나 개념들의 공통점이나 차이점을 설명하는 방식이며, 공통점과 차이점별로 나열해야 하는 내용은 대부분 대등한 관계여야 한다(Kim, 2004). 하지만 원인/결 과 구조는 선행하는 원인과 후행하는 결과의 인과적 관계를 이해
해야 하기 때문에 구조를 이해하는 데 어려움이 있었을 수 있고, 이 러한 구조의 특성이 학년 간 차이를 두드러지게 나타냈다고 볼 수 있다.

응집성 측면에서는 비교/대조, 원인/결과 구조 모두 학년이 올라 갈수록 글을 적절하게 통합하여 하나의 중심 문장을 산출할 수 있 었으며, 응집성을 떨어뜨리는 문장의 산출도 줄어들었고, 응집성 을 높이는 결속표지의 사용률도 높아졌다. 응집성에 포함된 세부 요소들 및 총 점수는 모든 학년 간 유의한 차이를 보여 다른 지표보 다 발달적 차이를 뚜렷하게 보여주는 지표라고 할수 있다.

중심문장을 찾는 지표와 관련해서 2 학년 학생들은 중심 문장이 나 중심 내용을 포함하는 구를 거의 산출하지 않았고, 4 학년 집단 은 완벽한 문장으로는 산출하지 않았으나 중심 내용을 포함하는 구를 산출할 수 있었다. 6 학년은 대부분 학생들이 중심 내용을 포 함하는 문장을 산출할 수 있었다. 이는 학년이 올라갈수록 중심 문 장을 적절하게 구성할 수 있었고, 주제가 잘 드러난 설명담화를 만 들 수 있다는 선행연구들의 결과와 비슷하다(Ahn \& Kim, 2010; Brown \& Day, 1983). Lundine과 McCauley (2016)는 이러한 특성 을 노출의 경험으로 언급하면서 학년이 올라갈수록 교과과정에서 중심내용을 찾는 활동들이 빈번해지기 때문에 고학년에서 중심문 장을 재구성하는 수행력이 좋아진다고 설명하였다.

요약하는 문장 간에는 긴밀성이 유지되어야 하며, 이러한 긴밀성 은 결속표지를 통해 두드러지게 나타난다. 설명담화를 읽고 적절히 요약하기 위해서는 언어적 능력뿐 아니라 문장을 적절히 배치하고, 정보를 통합하여 긴밀하게 정리하는 상위인지능력도 중요하다. 2 학년은 주제와 관련이 없는 문장을 산출하지는 않았으나 도식자료 에 포함된 어휘를 그대로 산출하여 긴밀성이 떨어지는 모습들이 빈 번하게 나타나 요약하기와 관련한 상위인지능력이 충분히 발달하 지 않은 것으로 해석되었다. 또한 설명담화와 도식에 일부 결속표지 가 제시되었음에도 불구하고 결속표지를 사용하여 문장을 긴밀하 게 연결하는 데에도 어려움을 보였다. 4학년에서도 때때로 긴밀성 을 떨어뜨리는 문장이 있긴 했지만 빈도가 낮았고, 6 학년에서는 긴 밀성을 떨어뜨리는 문장이 거의 없었다. 4 학년과 6 학년 학생들은 결속표지도 다양하게 사용하였다. 설명담화 내에 제시된 결속표지 뿐 아니라 자발적으로 다른 결속표지들도 사용해 요약하는 모습 을 보여 연령이 증가할수록 결속표지가 계속적으로 발달한다는 선 행연구를 뒷받침하는 결과라고 볼 수 있다(Kwon \& Pae, 2006; Lee \& Jung, 2013; Yang, 2000). 아동들이 사용한 결속표지도 선행연구 에서 나온 결과와 유사했는데(Lee \& Jung, 2013), 연결어미의 사용 이 가장 많았고, 그 다음 보조사, 어휘적 결속의 사용이 많았다. 연 결어미의 사용이 빈번했던 또 다른 이유는 본 연구에서 사용한 설 
명담화의 구조로 설명할 수 있다. 비교/대조 구조는 공통점과 차이 점을 설명하기 위해 나열이나 대조의 연결어미를 빈번하게 사용하 였으며, 원인/결과 구조에서는 선행하는 사건과 후행하는 결과를 나타내기 위한 '-서’ 등의 종속적 연결어미를 사용해야하기 때문에 더 빈번하게 나타난 것으로 해석할 수 있다. 접속사나 연결어미는 다음 글의 내용을 예측하는 일종의 단서가 되고, 이를 통해 내용을 통합하여 조직화하는 데 도움을 준다(Lundine \& MaCauley, 2016). 학년이 올라가면서 글에 제시된 접속사와 연결어미, 어휘 등 결속 표지를 확인하여 설명담화의 거시구조를 이해하고, 이를 다시 요 약하는 데 적절하게 사용한 것으로 보인다.

마지막으로 요약하기에 나타난 언어적 표지로서 어휘 산출성과 구문적 복잡성을 살펴보았을 때 학년이 올라갈수록 요약하기에서 다양한 어휘와 복잡한 구문을 사용하는 것으로 나타났다. 어휘 산 출성을 알아보기 위해 분석한 NDW는 비교/대조 구조와 원인/결 과 구조 모두 2 학년과 4 학년, 2 학년과 6학년 간 유의한 증진을 보였 다. 이는 선행연구들(Ahn \& Kim, 2010; Kim \& Kim, 2011; Lee \& Jung, 2013; Nippold et al., 2005)의 결과와 비슷한 맥락에 해당한다 고 볼 수 있으며, 학년이 올라가면서 아동이 사용할 수 있는 어휘의 수가 꾸준히 증가하여 어휘를 다양하게 산출하는 능력이 학령기 이후에도 계속적으로 발달한다는 것을 뜻한다. 2 학년 학생은 4,6 학년 학생에 비해 어휘의 양이 적었으며, 어휘를 사용할 때 의미적 오류를 보이기도 하였다. 또한 추상어나 동의어, 반의어 등 고급한 어휘의 빈도 수도 낮았다. 예를 들면, 중심 문장과 관련된 어휘나 설 명담화의 구조를 드러내는 어휘(예: 차이점, 공통점, 원인, 결과 등) 를 사용하는 빈도가 낮았으며, 오류('연락처’라는 의미를 정확하게 파악하지 못해 '연라처', 혹은 '얄라처'라고 쓰고, 그대로 산출한 경 우)도 때때로 관찰되었다. 반면 4,6학년 학생은 중심 문장을 표현 하기 위하여 내용과 관련된 다양한 어휘들을 사용하였고, 하위 내 용을 설명담화 구조에 맞게 산출하기 위하여 추상적인 어휘나 구 체적인 어휘 등 질적으로 고급한 어휘나, 혹은 이미 나온 어휘나 개 념을 상위어로 다양하게 표현하였다. 다양한 어휘를 적절하게 산출 한 것은 응집성 지표의 결속표지 사용이나 문장 간의 긴밀성 점수 에도 영향을 주었다.

MLC-w는 비교/대조 구조에서는 2학년과 4학년, 2학년과 6학년 간 유의한 차이를 보였으며, 원인/결과 구조에서는 2학년과 6학년, 4 학년과 6학년 간 유의한 차이를 보였다. 이는 학년이 올라갈수록 복잡한 구문을 사용한다는 선행연구들(Ahn \& Kim, 2010; Kim \& Kim, 2011; Nippold et al., 2005; Nippold, 2007)의 결과와 비슷하다 고 해석할 수 있다. MNC는 두 설명담화 구조 모두 2학년과 6학년 간 유의한 차이를 보였다. 이는 학년이 올라갈수록 설명담화를 요
약하여 산출할 때, 다양한 종속절을 포함하여 적절하게 산출할 수 있었던 것으로 해석할 수 있으며, T-unit으로 구문복잡성을 분석 한 선행연구들(Kim \& Kim, 2011; Kwon \& Pae, 2006; Lee, Kim, \& Yoon, 2008; Nippold et al., 2005)과도 일치하는 결과이다. Kwon과 $\mathrm{Pae}$ (2006)의 연구에서는 MNC가 학년이 증가할수록 유의하게 증 가하여 발달을 측정하는 데 유용한 척도가 될 수 있다고 하였다. 본 연구에서는 두 설명담화 구조 모두 2학년과 6학년 간만 유의한 증 진을 보였다. 2학년 학생들은 도식을 채울 때 때때로 쓰기 오류가 나타났으며, 이를 수정하지 않고 그대로 산출하여 구문 오류가 나 타나기도 하였다. 또한 본인이 산출하는 문장에 적절하게 연결어미 를 사용하는 것이 아니라 도식에 제시된 연결어미를 그대로 사용하 면서 부적절한 문장을 산출하기도 하였다. 각 학년집단의 문장구 조를 살펴보면 2학년은 $50 \%$ 이상의 문장이 단문인 데 비해, 4 학년 과 6학년은 단문산출보다 복문산출이 많았으며, 종속절도 빈번하 게 사용하였다. 2 학년 학생들의 문장이 대부분 단문이었던 것은 설 명담화의 특성에 기인한 것으로 설명할 수 있다. 설명담화는 이야 기담화보다 저빈도 어휘의 사용과 복잡하고 긴 구문의 사용이 빈 번하기 때문에 이러한 특성이 복잡한 구문을 산출하는 데 영향을 미쳤을 수 있다(Lundine \& McCauley, 2016). 그래서 언어와 인지적 어려움이 없는 학생들임에도 불구하고 여전히 구문에서 단문의 산 출이 높고, 오류도 빈번하게 나타난 것으로 보인다.

본 연구의 결과를 종합해 볼 때, 학년이 올라갈수록 설명담화 구 조에 따른 도식을 적절하게 사용하고, 도식을 사용하여 중심 문장 을 생성할 수 있었고, 설명담화 구조에 맞게 문장들을 긴밀하게 연 결하여 논리적으로 요약할 수 있었다. 또한 내용을 풍부하게 하기 위하여 다양한 어휘들을 사용하며, 종속절을 포함하여 더 복잡한 구문을 산출할 수 있었다.

설명담화를 요약하는 능력은 복잡하고 높은 수준의 인지적 요 구가 있는 과제이다. 이미 알고 있는 지식과 읽으면서 새롭게 들어 오는 정보를 함께 통합할 수 있어야 하며, 설명담화의 구조에 맞게 조직화하기 위한 전략을 자발적으로 계획해야 한다. 이때 중심문 장과 이를 뒷받침하는 문장을 확인하고, 불필요한 정보는 억제하 고 중요한 정보만 언급해야 한다. 이러한 전반적인 과정을 살펴볼 수 있는 요약하기 과제는 설명담화에 대한 전반적 이해가 있는지에 대한 지표를 제공한다. 대부분의 연구들이 설명담화의 미시구조적 인 측면을 살펴보았는 데 반해 본 연구는 설명담화 요약하기를 통 해 거시구조도 함께 살펴보고자 하였다. 본 연구결과를 통해 설명 담화에 대한 전반적인 이해와 표현이 학년이 올라갈수록 증진된다 는 것이 드러났다.

학년이 올라갈수록 교과과정 내에 설명담화의 비중이 높아지기 
때문에 설명담화 요약하기 능력은 학령기 언어장애아동의 평가와 중재에서도 고려되어야 할 부분이라고 할 수 있을 것이다. 본 연구 는 교과과정에서 빈번하게 사용되는 두 설명담화 구조인 비교/대 조와 원인/결과만을 살펴보았으며, 주제의 친숙성이 요약하는 데 영향을 미칠 수 있어 두 담화 간에 요약하기를 비교하는 데에는 무 리가 있었다. 일부 연구에서 설명담화의 구조에 따라 요약하는 데 차이가 있었기 때문에(Lundine et al., 2018), 추후 연구에서는 교과 과정에서 나타나는 다양한 설명담화 구조 간에 차이를 살펴보는 것이 필요할 것이다.

\section{REFERENCES}

Ahn, E. J., \& Kim, J. (2010). Expository writing abilities of school-aged children. Korean Journal of Communication \& Disorders, 15, 321-336.

Brown, A. L., \& Day, J. D. (1983). Macrorules for summarizing texts: the development of expertise. Journal of Verbal Learning and Verbal Behavior, 22, 1-14.

Chall, J. (1983). Stages of reading development. New York, NY: McGraw-Hill.

Englert, C. S., \& Hiebert, E. H. (1984). Children's developing awareness of text structures in expository materials. Journal of Educational Psychology, 76, 65-74.

Ghaith, G. M., \& Harkouss, S. A. (2003). Role of text structure awareness in the recall of expository discourse. Foreign Language Annals, 36, 86-96.

Graesser, A., \& Li, J. Z. (2013). How might comprehension deficits be explained by the constraints of text and multilevel discourse processes? In B. Miller et al. (Eds.), Unraveling reading comprehension: behavioral, neurobiological, and genetic components (pp. 33-42). Baltimore, MD: Brookes.

Ju, N. (2016). Characteristics of the text structure shown in expository writings by elementary school learners and teaching method (Master's thesis). Gwangju National University of Education, Gwangju, Korea.

Jung, J. S. (2011). Examination of the summarization activities in Korean elementary textbooks. Subjective Education Research, 15, 165-183.

Jung, K. H., Jin, Y. S., Gwak, K. M., Kim, M. B., \& Pae, S. Y. (2017). Korean Haedokhae (3rd ed.). Seoul: Hakjisa.

Kamhi, A. G., \& Catts, H. W. (2012). Language and reading disabilities. New York, NY: Pearson.

Kieras, D. E., \& Polson, P. G. (1985). An approach to the formal analysis of user complexity. International Journal of Man-Machine Studies, 22, 365394.

Kim, J. S. (2004). The study of teaching program by each steps of explanatory speaking (Master's thesis). Pusan National University of Education, Busan, Korea.

Kim, J. S., \& Kim, J. M. (2011). Characteristics of syntactic ability of schoolage children and adolescents in expository and narrative tasks. Korean Journal of Communication \& Disorders, 16, 540-558.

Kim, Y. T., Hong, K. H., Kim, K. H., Jang, H. S., \& Lee, J. Y. (2009). Receptive \& Expressive Vocabulary Test (REVT). Seoul: Seoul Community Rehabilitation Center.

Kintsch, E. (1990). Macroprocesses and microprocesses in the development of summarization skill. Cognition and Instruction, 7, 161-195.

Kintsch, W. (2004). The construction-integration model of text comprehension and its implications for instruction. In B. R. Robert \& J. U. Norman (Eds.), Theoretical models and processes of reading (5th ed., pp. 1270-1328). Newark, DE: International Reading Association.

Kwon, Y. J., \& Pae, S. Y. (2006). Story composition ability of Korean children in Chuncheon with a story generation task. Journal of Speech \& Hearing Disorders, 15, 115-126.

Lee, H. J., Kim, Y. T., \& Yoon, H. R. (2008). Characteristic of syntactic complexity in school-aged children with specific language impairment: a comparison of conversation and expository discourses. Korean Journal of Communication Disorders, 13, 103-121.

Lee, H. Y., \& Jung, K. H. (2013). Development of spoken and written expository discourse in school-aged children. Journal of Speech \& Hearing Disorders, 22, 145-161.

Lee, M. R., \& Lee, H. R. (2014). Characteristics of the spoken expository discourse of 3-4 grade school-aged children with language learning disabilities. Communication Sciences \& Disorders, 19, 456-466.

Lundine, J. P., \& McCauley, R. J. (2016). A tutorial on expository discourse: structure, development, and disorders in children and adolescents. American Journal of Speech-Language Pathology, 25, 306-320.

Lundine, J. P., Harnish, S. M., McCauley, R. J., Blackett, D. S., Zezinka, A., Chen, W., \& Fox, R. A. (2018). Adolescent summaries of narrative and expository discourse: differences and predictors. Language, Speech, and Hearing Services in Schools, 49, 551-568.

Marzano, R. J., Pickering, D. J., \& Pollock, J. E. (2001). Classroom instruction that works: research-based strategies for increasing student achievement. Alexandria, VA: Association for Supervision and Curriculum Development.

Meyer, B. J., Brandt, B. J., \& Bluth, G. J. (1980). Use of top-level structure in text: key for reading comprehension for ninth-grade students. Reading Research Quarterly, 16, 72-103. 
Meyer, B. J., \& Freedle, R. O. (1984). Effects of discourse type on recall. American Educational Research Journal, 21, 121-143.

Meyer, B. J., \& Rice, G. E. (1982). The interaction of reader strategies and the organization of text. Text, Interdisciplinary Journal for the Study of Discourse, 2, 155-192.

National Reading Panel. (2000). Teaching children to read: an evidence-based assessment of the scientific research literature on reading and its implications for reading instruction. Washington, DC: US Department of Health and Human Services.

Nippold, M. A. (2007). Later language development: school-aged children, adolescents, and young adults (3rd ed.). Austin, TX: Pro-Ed.

Nippold, M. A., Hesketh, L. J., Duthie, J. K., \& Mansfield, T. C. (2005). Conversational versus expository discourse: a study of syntactic development in children, adolescent, and adults. Journal of Speech, Language, and Hearing Research, 48, 1048-1064.

Owens, R. (2012). Language development: an introduction (6th ed.). New York, NY: Allyn \& Bacon.

Pae, S. Y., Kim, M. B., Yoon, H. J., \& Jang, S. M. (2015). Korean Language-based Reading Assessment (KOLRA). Seoul: Hakjisa.

Park, H. W. (2014). Korean Comprehensive Test of Nonverbal Intelligence-Second Edition (K-CTONI-2). Seoul: Mindpress.

Ray, M. N., \& Meyer, B. J. (2011). Individual differences in children’s knowledge of expository text structures: a review of literature. International Electronic Journal of Elementary Education, 4, 67-82.
Scott, C. M., \& Stokes, S. (1995). Measure of syntax in school-age children and adolescents. Language, Speech, and Hearing Services in Schools, 26, 309-319.

Smith, T. F., \& Hahn, A. L. (1989). Intermediate-grade students' sensitivity to macrostructure intrusions. Journal of Reading Behavior, 21, 167-180.

Sudweeks, R. R., Glissmeyer, C. B., Morrison, T. G., Wilcox, B. R., \& Tanner, M. W. (2003). Establishing reliable procedures for rating ELL students' reading comprehension using oral retellings. Literacy Research and Instruction, $43,65-86$

Westby, C. E., \& Clauser, P. S. (2005). The right stuff for writing assessing and facilitating written language. In H. W. Catts \& A. G. Kamhi (Eds.), Language and reading disabilities (pp. 259-324). New York, NY: Pearson.

Westby, C. E., Cluatta, B., Lawrence, B., \& Hall-Kenyon, K. (2010). Summarizing expository texts. Topics in Language Disorders, 30, 275-287.

Wylie, J., \& McGuinness, C. (2004). The interactive effects of prior knowledge and text structure on memory for cognitive psychology texts. British Journal of Educational Psychology, 74, 497-514.

Yang, S. J. (2000). The development of cohesion on the narratives of Koreanspeaking children aged 4, 6, 8 and adults (Master's thesis). Ewha Womans University, Seoul, Korea.

Yoon, S. K. (2008). The effects of summarizing activities on the middle school students' expository writing (Master's thesis). Catholic University of Education, Bucheon, Korea. 
Appendix 1. 요약하기 채점 기준

\begin{tabular}{|c|c|c|c|c|c|}
\hline \multirow{2}{*}{$\begin{array}{l}\text { 채점할 } \\
\text { 자료 }\end{array}$} & \multicolumn{2}{|c|}{ 채점 기준 } & \multicolumn{3}{|c|}{ 점수 } \\
\hline & $\begin{array}{l}\text { 채점 } \\
\text { 기준 }\end{array}$ & $\begin{array}{l}\text { 세부적인 } \\
\text { 채점기준 }\end{array}$ & 0점 & 1점 & 2점 \\
\hline 도식 & & $\begin{array}{l}\text { 도식 } \\
\text { 채우기 }\end{array}$ & $\begin{array}{l}\text { (1) 도식에 글 자료에 제시된 내용을 } \\
50 \% \text { 미만 적절하게 채웠음 } \\
\text { - 비교/대조 구조: 4개 이하 } \\
\text { - 원인/결과 구조: } 6 \text { 개 이하 } \\
\text { (2) 글 자료 내용을 그대로 옮겨 적음 }\end{array}$ & $\begin{array}{l}\text { (1) 도식에 제시된 문항을 50\%-80\% } \\
\text { 적절하게 채웠음 } \\
\text { - 비교/대조 구조: 5-7개 } \\
\text { - 원인/결과 구조: 7-10개 }\end{array}$ & $\begin{array}{l}\text { (1) 도식에 제시된 문항을 } 80 \% \text { 이상 적절하게 } \\
\text { 채웠음 } \\
\text { - 비교/대조 구조: } 8 \text { 개 이상 } \\
\text { - 원인/결과 구조: } 11 \text { 개 이상 }\end{array}$ \\
\hline $\begin{array}{c}\text { 산출한 } \\
\text { 발화 }\end{array}$ & 조직성 & $\begin{array}{c}\text { 도식 } \\
\text { 사용하여 } \\
\text { 요약하기 }\end{array}$ & $\begin{array}{l}\text { (1) 텍스트 요약의 시도가 거의 없거나 전 } \\
\text { 혀 없음(예. '두 동물 모두 포유류이기 } \\
\text { 때문에 젖을 먹여 양육한다는 점이 동 } \\
\text { 일합니다'라는 문장을 그대로 도식에 } \\
\text { 채우고 산출함) }\end{array}$ & $\begin{array}{l}\text { (1) 도식에 있는 내용을 } 80 \% \text { 이상 사용하 } \\
\text { 여 문장으로 산출함 } \\
\text { (2) 도식에 제시되어 있는 부분을 그대로 나 } \\
\text { 열하기만 함(예: 동물, 호랑이, 토끼, } 1 \text { 차 } \\
\text { 피해, 지진에 대비할 수 있는 방안은 무 } \\
\text { 엇인가요?) }\end{array}$ & $\begin{array}{l}\text { (1) 도식에 포함된 내용을 글 요약 시 모두 포함 } \\
\text { 하여 문장으로 산출함 } \\
\text { (2) 도식화에 포함된 내용에 대해 자신이 다시 } \\
\text { 구조하고 계획하여 자신의 단어로 바꾸어 표 } \\
\text { 현함(예. '경계'라는 말을 첨가하여 '두 번째로 } \\
\text { 는 여러 개의 판들 사이에는 경계가 있는데 } \\
\text { 그 경계에서 판들끼리 부딫히면서 생기는 충 } \\
\text { 격으로 지진이 생길 수 있습니다.'로 문장 생 } \\
\text { 성함) }\end{array}$ \\
\hline $\begin{array}{c}\text { 산출한 } \\
\text { 발화 }\end{array}$ & & $\begin{array}{l}\text { 설명담화 } \\
\text { 구조 } \\
\text { 인식하기 }\end{array}$ & $\begin{array}{l}\text { (1) 문장들이 각 설명담화 구조에 적절하 } \\
\text { 지 않음 } \\
\text { (2) 문장이 지나치게 짧고 분명하지 않아 } \\
\text { 조직성을 평가하기 어려움(예. 단어들 } \\
\text { 만 나열하거나 문장이 아닌 구로 산출 } \\
\text { 하는 경우) }\end{array}$ & $\begin{array}{l}\text { (1) 설명담화 구조는 대략적으로 존재하지 } \\
\text { 만 명확하게 제시되지 않음 } \\
\text { (2) 각각의 구조별로 1-2문장 정도 단순하게 } \\
\text { 산출함(예: 호랑이는 몸집이 크고 토끼 } \\
\text { 는 몸집이 작다[차이점]. 호랑이와 토끼 } \\
\text { 는 양육방식이 같다[공통점]) }\end{array}$ & $\begin{array}{l}\text { (1) 구체적인 설명담화 구조를 사용함(비교/대 } \\
\text { 조, 원인/결과) } \\
\text { (2) 글의 전반적인 조직화에 영향을 주기 위해 } \\
\text { 모든 문장은 논리적으로 제시되었음 }\end{array}$ \\
\hline $\begin{array}{c}\text { 산출한 } \\
\text { 발화 }\end{array}$ & & 중심문장 & $\begin{array}{l}\text { (1) 중심 문장이 제시되지 않음 } \\
\text { (2) 요약한 문장들은 하나의 중심 문장에 } \\
\text { 전혀 연결되지 않음 }\end{array}$ & $\begin{array}{l}\text { (1) 중심 내용을 포함하는 문장이 존재하지 } \\
\text { 만, 글을 조직화하기에는 포괄적인 문장 } \\
\text { 혹은 중심내용이 포함된 구로 산출함 } \\
\text { - 비교/대조 구조: '호랑이와 토끼에 관 } \\
\text { 련된 글이다' 또는 ‘호랑이와 토끼의 차 } \\
\text { 이점은-' } \\
\text { - 원인/결과 구조: '지진에 관련된 글이 } \\
\text { 다' 또는 '지진이 일어나는 원인은 -' }\end{array}$ & $\begin{array}{l}\text { (1) 처음 시작하는 중심문장은 각 문단을 어떻게 } \\
\text { 조직화할 것인지에 대해 제시됨 } \\
\text { - 비교/대조 구조: '호랑이와 토끼의 공통점 } \\
\text { 과 차이점에 대해 이야기하고 있다' } \\
\text { - 원인/결과 구조: 지진이 일어나는 원인과 } \\
\text { 결과에 관련된 글이다. }\end{array}$ \\
\hline $\begin{array}{c}\text { 산출한 } \\
\text { 발화 }\end{array}$ & 응집성 & $\begin{array}{c}\text { 문장 간의 } \\
\text { 긴밀성 }\end{array}$ & $\begin{array}{l}\text { (1) 문장들이 서로 관련이 있지 않음 } \\
\text { (2) 문장들이 하나의 주제로 이어지지 않 } \\
\text { 음(예: ‘호랑이와 토끼'에서 사자 } \\
\text { 이야기) }\end{array}$ & $\begin{array}{l}\text { (1) 각 문장들은 대부분 주제와 연결된 문장 } \\
\text { 으로 표현되었음 } \\
\text { (2) } 1-2 \text { 문장 정도 주제와의 응집성을 떨어뜨 } \\
\text { 리는 문장이 존재할 수 있음 }\end{array}$ & $\begin{array}{l}\text { (1) 주제에 포함된 문장들은 명확하고 정확하게 } \\
\text { 표현되고, 적절하게 정교화되었음 } \\
\text { (2) 응집성을 떨어뜨리는 문장은 존재하지 않음 }\end{array}$ \\
\hline $\begin{array}{c}\text { 산출한 } \\
\text { 발화 }\end{array}$ & & 결속표지 & $\begin{array}{l}\text { (1) 글에 사용된 결속표지를 } 20 \% \text { 미만 } \\
\text { 사용하였음 } \\
\text { - 비교/대조 구조: } 13 \text { 개 미만 } \\
\text { - 원인/결과 구조: } 9 \text { 개 미만 } \\
\text { (2) 결속표지의 오류가 있음 }\end{array}$ & $\begin{array}{l}\text { (1) 글에 사용된 결속표지를 } 20 \%-50 \% \text { 이 } \\
\text { 상 사용하였음 } \\
\text { - 비교/대조 구조: } 14-33 \text { 개 } \\
\text { - 원인/결과 구조: } 10-24 \text { 개 } \\
\text { (2) 글 자료에 제시된 결속표지만을 사용함 }\end{array}$ & $\begin{array}{l}\text { (1) 글에 사용된 결속표지를 } 50 \% \text { 이상 사용하 } \\
\text { 였음 } \\
\text { - 비교/대조 구조: } 34 \text { 개 이상 } \\
\text {-원인/결과 구조: } 25 \text { 개 이상 } \\
\text { (2) 글 자료에 제시된 결속표지뿐만 아니라 새 } \\
\text { 로운 결속표지를 추가하여 산출함 }\end{array}$ \\
\hline
\end{tabular}




\title{
국문초록
}

\author{
비교/대조와 원인/결과를 중심으로 본 초등 2, 4, 6학년 일반아동의 설명담화 요약하기 능력 \\ 김보림'(언어치료사, 제1저자) · 윤효진'(교수, 교신저자) \\ 1참사랑정신건강의학과 의원, ${ }^{2}$ 조선대학교 언어치료학과
}

배경 및 목적: 본 연구는 초등 $2,4,6$ 학년을 대상으로 설명담화 요약하기 능력을 설명담화의 거시구조와 미시구조로 살펴보고자 하였 다. 설명담화는 초등학교 교과서에서 빈번하게 사용되는 비교/대조와 원인/결과의 두 구조를 사용하였다. 방법: 초등 $2,4,6$ 학년 학생 이 학년당 15 명씩 참여하여 총 45 명이 본 연구에 참여하였다. 본 연구는 비구어성지능검사에서 80 점 이상, 수용표현어휘력검사에서 -1 표준편차 이상, 한국어읽기검사의 읽기유창성 검사에서 표준점수 90 점 이상의 점수를 받은 학생들이 참여하였다. 학생들이 비교/대조 와 원인/결과 글을 읽은 후 연구자가 제시한 도식을 채우고, 도식을 이용하여 구어로 요약하도록 요구하였다. 도식과 구어로 요약한 발 화를 분석하였으며, 거시구조인 조직화, 응집성, 미시구조인 언어적 표지로서 NDW, MLC-w, MNC로 나누어 채점하였다. 각 설명담화 구조별로 일원분산분석을 사용하여 각 학년 집단 간에 차이가 있는지를 살펴보았다. 결과: 비교/대조와 원인/결과 모두 학년이 올라감 에 따라 요약하기 조직성, 응집성의 총 점수, 그리고 하위 세부 지표 모두에서 유의한 증가를 보이는 것으로 나타났다. 또한 언어적 지표 인 NDW, MLC-w, MNC도 학년이 올라갈수록 유의한 증진을 보였다. 특히, 응집성은 총 점수와 세부 지표 모두 모든 집단 간 유의한차 이를 보이는 것으로 나타났다. 논의 및 결론: 학년이 올라갈수록 설명담화를 요약할 때 정보를 적절하게 통합하고, 설명담화의 구조에 맞게 조직화하여 중심내용과 뒷받침하는 내용을 다양한 어휘와 복잡한 구문구조로 산출할 수 있었다. 교과과정에서 설명담화의 비중 이 점차 늘어나기 때문에 학령기 언어평가와 중재에서도 설명담화 요약하기가 고려되어야 할 것이다.

핵심어: 학령기, 설명담화, 요약하기 능력, 조직화, 응집성, 어휘, 구문복잡성

본 논문은 제 1 저자의 석사학위논문을 수정보완하였음.

\section{참고문헌}

권유진, 배소영(2006). 이야기만들기 과제를 통한 초등 저학년 아동의 야이기 구성 능력. 언어치료연구, 15, 115-126.

김영태, 홍경훈, 김경희, 장혜성, 이주연(2009). 수용·표현어휘력검사(Receptive \& Expressive Vocabulary Test). 서울: 서울장애인복지관.

김자성, 김정미(2011). 설명과 경험이야기에 나타난 학령기 아동 및 청소년의 구문발달 특성. 언어청각장애연구, 16, 540-558.

김정수(2004). 설명하는 말하기의 단계별 지도 프로그램 연구. 부산교육대학교 대학원 석사학위논문.

박혜원(2014). 한국 비언어지능검사 2판(K-CTONI-2). 서울: 마인드프레스.

배소영, 김미배, 윤효진, 장승민(2015). 한국어 읽기검사(KOLRA). 서울: 학지사.

안은주, 김정미(2010). 초등학교 2, 4, 6학년 아동의 설명담화 쓰기 비교. 언어청각장애연구, 15, 321-336.

양수진(2000). 이야기 결속표지 발달: 4세, 6 세, 8 세 및 성인을 대상으로. 이화여자대학교 대학원 석사학위논문.

윤선경(2008). 요약하기 활동이 설명담화 쓰기 능력에 미치는 영향. 가톨릭대학교 대학원 석사학위논문.

이미림, 이희란(2014). 설명담화 유형에 따른 초등학교 3-4학년 언어학습장애아동의 말하기 특성. Communication Sciences \& Disorders, 19, 456-

466.

이혜연, 정경희(2013). 학령기 아동의 설명담화 말하기와 쓰기 발달: 구문, 의미, 결속장치를 중심으로. 언어치료연구, 22, 145-161.

이현정, 김영태, 윤혜련(2008). 담화유형에 따른 학령기 단순언어장애 아동의 구문사용 특성: 대화와 설명 담화를 중심으로. 언어청각장애연구, 13, 103-121.

정경희, 진연선, 곽경미, 김미배, 배소영(2017). 한국어 해독해 3 권. 서울: 학지사.

정종성(2011). 초등학교 국어 교과서에 제시된 요약하기 학습 내용에 대한 분석. 교과교육학연구, 15, 165-183.

주난형(2016). 초등학생의 설명적 텍스트에 나타난 글 구조 특성과 지도방법연구. 광주교육대학교 대학원 석사학위논문. 